
Preliminary Report on the Gypsum Deposits near Iyoukeen Cove,
Chichagof Island, southeastern Alaska

\author{
by \\ George M. Flint, Jr. \\ and \\ Edward H. Cobb
}

Introduction

The only known gypsum deposits in Alaska are on northeastern Chichagof Island, southeastern A laska, at Iyoukeen Cove (fig. 1). The area first developed and for a time worked by the Pacific Coast Gypsum Co. is approximately 1 mile upstream from the mouth of Gypsum Creek at an elevation of about 70, feet (fig. 2). The second deposit, known as the Gypsum-Camel. property, is on tidewater $1 \frac{1}{2}$ miles northeast of the mouth of Gypsum Creek (fig. 2). Iyoukeen Cove is about 35 air miles southwest of Juneau and is on both the mail-boat and the airline routes between Juneau and Sitka.

The two deposits were examined by a Geological Survey party during the summer of 1946 . Topographic and geologic maps were made of the vicinity of both deposits (figs. 2 and 3 ). Accessible underground workings at the Gypsum-Camel property also were mapped.

\title{
Development
}

Operations at the Gypsum Creek deposit began in 1906 and continued until December 1923. Shafts, by means of which the property was developed, are now caved or flooded. Stewart 1 /reported that the workings were 300 feet deep with a lateral extent of $\overline{6} 00$ by. 800 feet. Either recurrent flooding of the workings by surface water or exhaustion of the deposit caused the abandonment of the mine. The property probably produced half a million tons of gypsum. 2/ A pier 2,000 feet long, a surface tram line 1 mile long, and miscellaneous mine and maintenance buildings on the property are now in ruins.

Workings on the Gypsum-Camel property consist of five adits (fig. 3) driven from the beach about 15 feet above high tide. The adits extend under a gently sloping bench which is approximately 100 feet above sea level at its seaward edge. Adits 1 and 5 do not penetrate gypsum. Adits 2, 3, and 4211 expose gypsum between 100 and 160 feet from the portals (fig.4). $A$ winze and an incline in Adit 3 are now inaccessible, but are reported to have encountered gypsum. 3/ The property never was worked commercially, but development work was carried on intermittently for about 15 years prior to World War II. 
Two log cabins, a cookhouse, and several outbuildings are on the property and are still usable. A pier which was never completed is in bad condition.

\section{General geology}

The oldest rocks exposed in the area are considered to be of Carboniferous age by Wright 4/ and Burchard 5/ and of lower Carboniferous age (Mississippian) by Kindle. 6/ These rocks are predominantly gray, coursely crystalline limestones containing some black chert. Numerous andesitic or basaltic dikes, usually less than 15 feet thick, intrude the limestone with no apparent regularity. The highest exposed unit of the sequence appears to be a buff limestone breccia composed of angular and subangular fragments of limestone in a matrix of cream or buff limestone. The longest dimension of the breccia fragments ranges from one-quarter of an inch to 3 feet.

Only three small outcrops of gypsum, all in the imnediate vicinity of the old workings (fig. 2), were observed in the area of the deposit on Gypsum Creek. On the Gypsum-Camel property gypsum is exposed only in the underground workings (fig. 4). The lower contact of the gypsum is not visible in either area, but the field relations suggest that the gypsum overlies the limestone breccia. The similarity of the stratigraphic relationship between the gypsum and the limestone sequence in both areas indicates the likelihood that both gypsum deposits are of the same age. The gypsum in the deposit on Gypsum Creek has been considered to be of Permian or Triassic age by Wright Z/ and Permian by Burchard.8/

Quaternary marine, fluviatile, and glacial deposits with a thick cover of vegetation conceal bedrock except on ridges and in a few creek beds.

\section{Gypsum deposits}

The gypsum taken from the deposit on Gypsum Creek is reported by Stewart 9/ to have been similar to that in the workings at the GypsumCamel property. The material is translucent, fine-grained, white rock gypsum with irregular narrow gray bands, and much of it approaches alabaster in grade. No anhydrite was found during the present investigation.

Old drainage channels and sinks occur in the deposit. Most are filled with gravel identical with the modern stream gravels nearby. 10/

The top few feet of the gypsum at the Gypsum-Camel property are fractured and solution-pitted. They consist principally of blocks of gypsum separated by clay. Nowhere in the deposit can bedding be determined with certainty. 
Possibilities for development

No valid estimate of gypsum reserves can be made for either deposit from available data.

Future development work on the deposit on Gypsum Creek would entail the diversion of Gypsum Creek and pumping out of at least a part of the old workings.

At the Gypsum-Camel property a modest drilling program with both vertical and horizontal holes from near the faces of Adits 2 and 3 (fig. 4 ) might contribute sufficient data to permit the blocking out of enough gypsum to justify commercial operation. No estimate of the southwestward extent of the deposit can be made because of the lack of exposures away from the beach, but vertical drill holes from the bench (fig. 3) should indicate the lateral extent of the deposit. The outcrops of limestone breccia near Adits $I$ and 5 probably delimit the extent of this deposit along the shoreline.

Timber required for development and operations is available from the stands of hemlock and Sitka spruce in the area. Streams in the vicinity of the Gypsum-Camel property are not adequate as a source of power.

Iyoukeen Cove near the mouth of Gypsum Creek is slightly protected from storms by North Passage Point, but because of the gently sloping tidal flats, a pier over 2;000 feet long would be necessary to permit docking of oceangoing vessels. The small point south of the Gypsum-Camel property affords some protection and the water is deep enough to requirs only a relatively short pier. 


\section{References}

1/ Stewart, B. D., The occurrence of gypsum at Iyoukeen Cove, Chichagof Island, Alaska: U. S. Geol. Survey Bull. 824, p. 173, 1931.

2) Stewart, B. D., op. cit., p. 173.

3/ Housel, Dave, Personal communication.

4f Wright, c. W. The building stones and materials of southeastern Alaska:

U. S. Geol. Survey Bull. 345, p. 124, 1908.

5/ Stone, R. W., and others, Gypsum deposits of the United States:

U. S. Geol. Survey Bull. 697, p. 47, 1920.

6/ Kindle, E. M., Notes on the Paleozoic faunas and stratigraphy of southeastern Alaska: Jour. Geology; vol. 15, pp. 330-331, 1967.

7) Wright, C. W., op. cit. p. 124 .

8/ Stone, R. W., and others, op. cit., p. 47.

9) Stewart, B. D., op. cit., p. 173.

10/ Wright, c. W., op r cit., p. 124. 


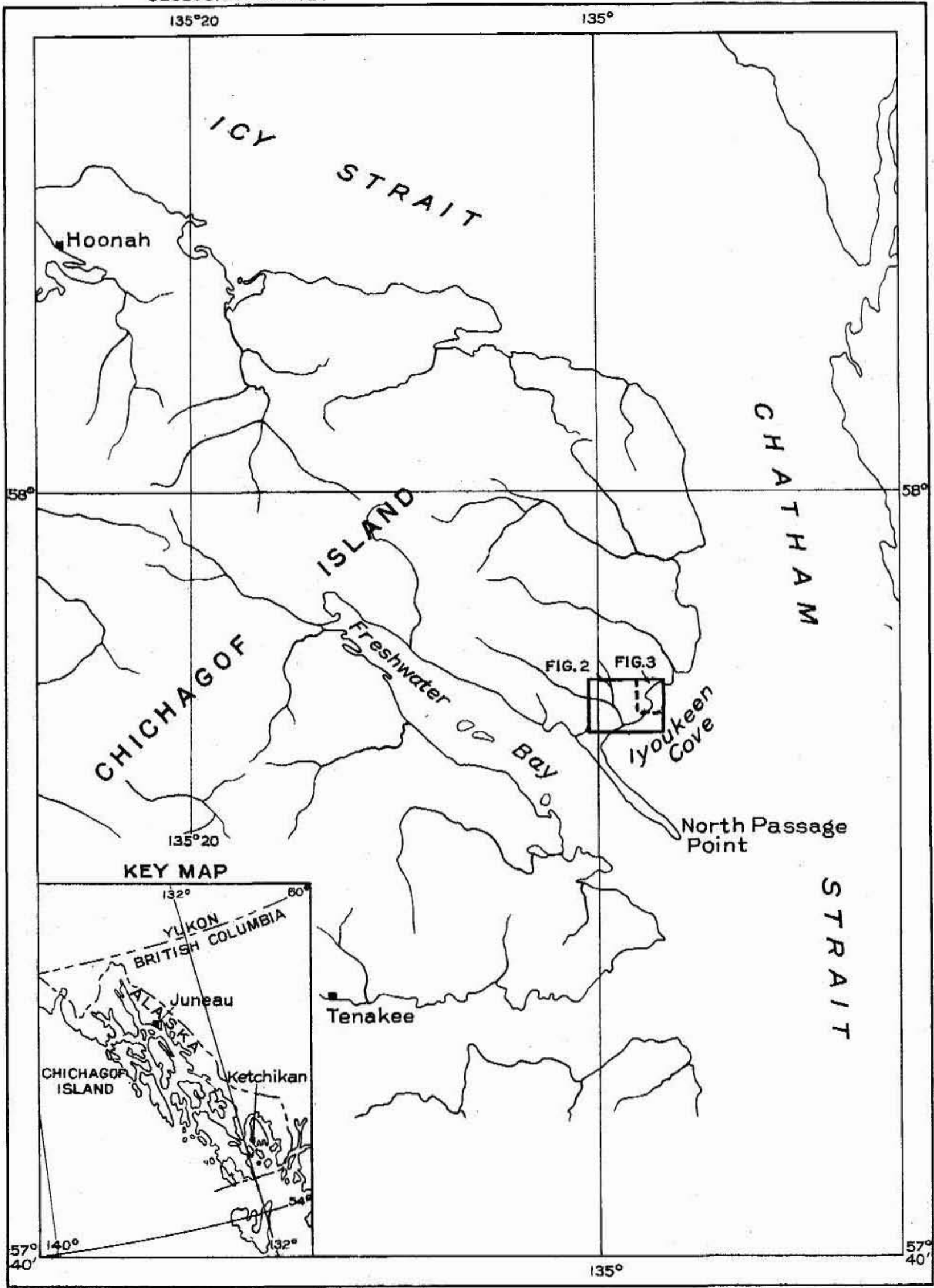

INDEX MAP OF NORTHEASTERN CHICHAGOF ISLAND, SOUTHEASTERN ALASKA 


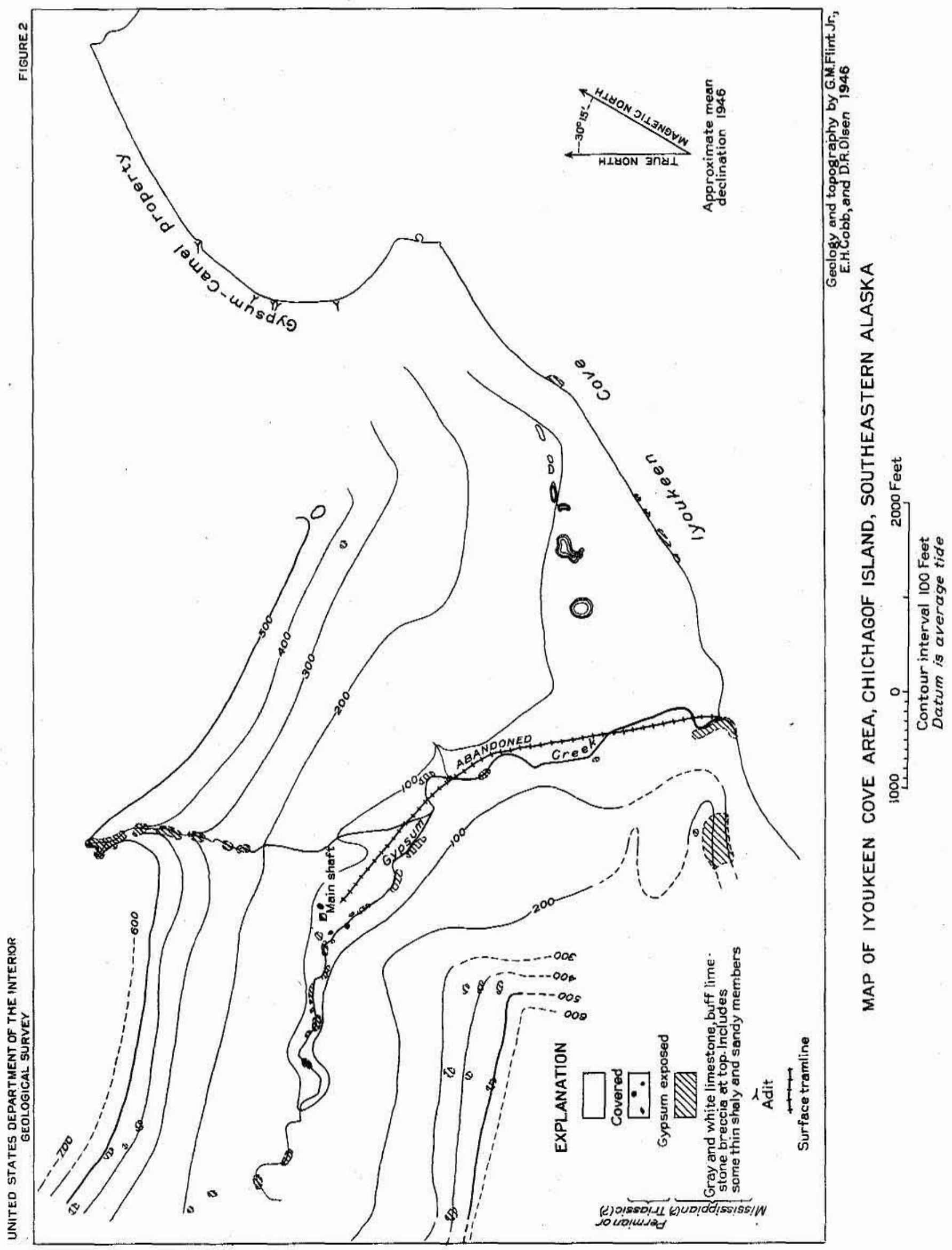




\section{EXPLANATION}

UMCONSOLIDATED BEACH GRAVEL

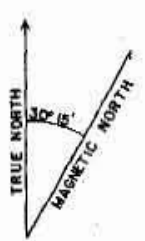

TYT GYUM AND OYPSIFEROUS CLAY

... OONTACT

$\otimes$

WINZE

GEOLOBY BY G.M.FLINT, Jh.

ANO E.H. COBB

1946

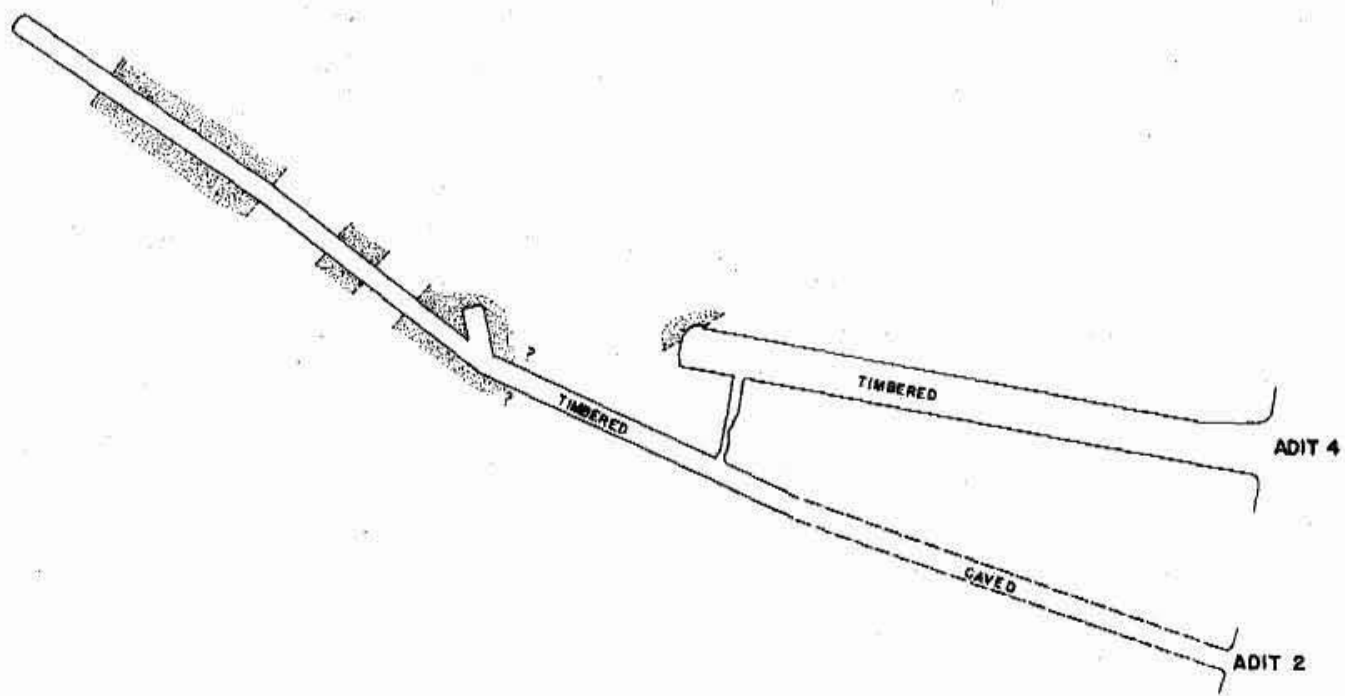

GEOLOGIC MAP, MAIN WORKNGS, GYPSUM-CAMEL PROPERTYY,

IYOUKEEN COVE, CHICHAGOF ISLAND, SOUTHEASTERN ALASKA

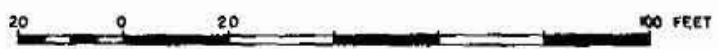

